\title{
TAVR in a patient with a membranous ventricular septal aneurysm identified during cardiac CT
}

\author{
Zafir A Hawa, ${ }^{1}$ Aasim Hawa, ${ }^{1}$ Jim Mitchell, ${ }^{1}$ Keith Allen ${ }^{2}$
}

${ }^{1}$ Cardiology, North Kansas City Hospital, North Kansas City, Missouri, USA

${ }^{2}$ Department of Cardiothoracic/ Vascular Surgery, St Luke's Mid America Heart \& Vascular Institute, Kansas City, Missouri, USA

Correspondence to Dr Zafir A Hawa, zahawa@hotmail.com

Accepted 16 June 2019

\section{DESCRIPTION}

Ventricular septal aneurysm is a congenital defect found frequently in association with ventricular septal defects. Its detection has been increasing particularly in the era of non-invasive imaging. The clinical relevance of an incidentally detected aneurysm of the membranous ventricular septum (AMVS) in adults is unclear. Although most patients with AMVS are asymptomatic, various complications including cerebral embolism, cardiac arrhythmias, right ventricular outflow tract obstruction, bacterial endocarditis and rupture causing shunting may occur. ${ }^{1}$ It has been previously reported that cardiac CT may be one of the best imaging modalities available in identifying these aneurysms. ${ }^{2}$ Additionally, multislice CT has the advantage of three-dimensional morphological display. ${ }^{3}$

We describe herein for the first time, a patient who had a transcatheter aortic valve replacement with a pre-existing ventricular septal aneurysm. She is a 72-year-old female patient with a history of rheumatic heart disease, status post-previous 25-mm St Jude's mitral valve replacement in 1988 for rheumatic mitral stenosis, who was referred to the multidisciplinary valve clinic for consideration for a transcatheter aortic valve replacement (TAVR) for severe aortic stenosis (AS). She had been having progressively increasing shortness of breath over the previous 6 months most consistent with New York Heart Association class III.

We were fortunate in having multiple diagnostic modalities available to evaluate this patient prior to her procedure. An echocardiogram showed severe AS with a mean gradient of $38 \mathrm{~mm} \mathrm{Hg}$ and a peak velocity of $4.13 \mathrm{~m} / \mathrm{s}$. Cardiac CT was able to most

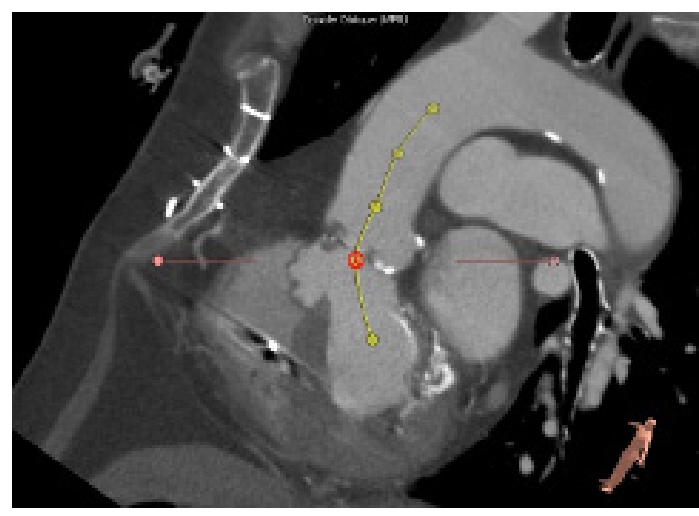

Figure 1 Baseline cardiac CT image in the long-axis view showing the membranous septal aneurysm and its relationship to the aortic annulus.

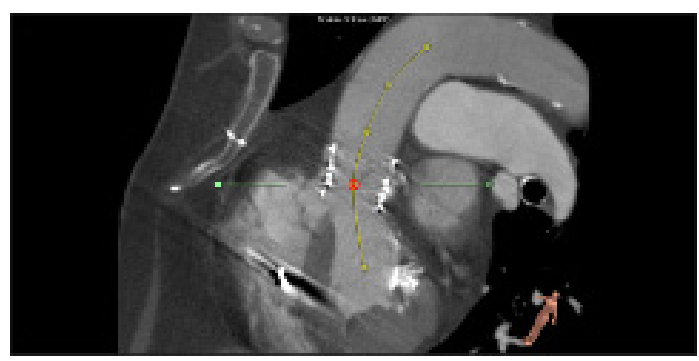

Figure 2 Post-transcatheter aortic valve replacement (post-TAVR) cardiac CT image in the long-axis view showing the membranous septal aneurysm and its relationship to the implanted TAVR.

clearly delineate the anatomy and location of the aneurysm. We could not perform a cardiac MRI on this patient as she had a non-MRI compatible pacemaker.

A TAVR CT done in preparation for her valve clinic visit showed aortic annulus area of $383 \mathrm{~mm}^{2}$ and an aortic annulus mean diameter of $21.8 \mathrm{~mm}$. It also showed an outpouching of the membranous septum at the left ventricular outflow tract measuring $12.1 \times 10 \mathrm{~mm}$ consistent with membranous ventricular septal aneurysm (figure 1). A Transesophageal Echocardiogram done to confirm these findings again demonstrated a ventricular septal aneurysm that was approximately $6 \mathrm{~mm}$ below the aortic annulus.

We had an internal discussion regarding the choice of valve (balloon-expanding vs self-expanding). We ultimately decided on an Edwards Sapien S3 valve as the team felt that this would ensure a controlled placement avoiding the aneurysm as much as possible. Our concern was ensuring the stability of the new valve and avoiding paravalvular leaks.

The patient subsequently underwent a successful TAVR using a $23-\mathrm{mm}$ Edwards Sapien S3 valve with trivial paravalvular aortic insufficiency identified on intraoperative TEE. She had

\section{Patient's perspective}

I was extremely excited when I was told about a new procedure that was available to fix my valve. Under any circumstances, I did not want to be cut open again. When I was told about the aneurysm, I thought to myself, whatever will be will be. I did not care much about the aneurysm. I just did not want to go through open heart surgery again. I am happy to say I feel wonderful after the procedure. 


\section{Learning points}

- Ventricular septal aneurysm is a rare congenital defect found frequently in association with ventricular septal defects.

- Transcatheter aortic valve replacement is an option for treating aortic stenosis in patients with a pre-existing ventricular septal aneurysm who are not otherwise candidates for surgery.

an uneventful postoperative course and was discharged home on postoperative day 6 once her International Normalized Ratio was therapeutic. An echocardiogram done 1-month post-TAVR demonstrated a mean gradient of $6 \mathrm{~mm} \mathrm{Hg}$ and no evidence of paravalvular aortic insufficiency. A cardiac CT done 4 months post-TAVR demonstrated a well-seated valve that had been placed just above the aneurysm (figure 2).
Contributors $\mathrm{ZAH}, \mathrm{JM}$ and $\mathrm{KA}$ conducted the procedure, reviewed the manuscript and made corrections. AH interviewed the patient, created the manuscript and helped format the images and upload the article.

Funding The authors have not declared a specific grant for this research from any funding agency in the public, commercial or not-for-profit sectors.

Competing interests None declared.

Patient consent for publication Obtained.

Provenance and peer review Not commissioned; externally peer reviewed.

\section{REFERENCES}

1 Meier JH, Seward JB, Miller FA, et al. Aneurysms in the left ventricular outflow tract: clinical presentation, causes, and echocardiographic features. J Am Soc Echocardiogr 1998;11:729-45.

2 Afaneh A, Et al. Membranous ventrcular septal aneurysm: Diagnosed by means of cardiac computed tomography. Texas Heart I 2012;39:450-1.

3 Komatsu S, Sato Y, Omori Y, et al. Aneurysm of the membranous interventricular septum demonstrated by multislice computed tomography. Int J Cardiol 2007;114:123-4.

Copyright 2019 BMJ Publishing Group. All rights reserved. For permission to reuse any of this content visit

https://www.bmj.com/company/products-services/rights-and-licensing/permissions/

BMJ Case Report Fellows may re-use this article for personal use and teaching without any further permission.

Become a Fellow of BMJ Case Reports today and you can:

- Submit as many cases as you like

- Enjoy fast sympathetic peer review and rapid publication of accepted articles

- Access all the published articles

- Re-use any of the published material for personal use and teaching without further permission

Customer Service

If you have any further queries about your subscription, please contact our customer services team on +44 (0) 2071111105 or via email at support@bmj.com.

Visit casereports.bmj.com for more articles like this and to become a Fellow 